Article

\title{
New Records of Fish Parasitic Isopods (Crustacea: Isopoda) from the Gulf of Thailand
}

\author{
Watchariya Purivirojkul *(D) and Apiruedee Songsuk \\ Animal Systematics and Ecology Speciality Research Unit, Department of Zoology, Faculty of Science, \\ Kasetsart University, Bangkok 10900, Thailand; Apiruedee.s@outlook.com \\ * Correspondence: fsciwyp@ku.ac.th
}

Received: 5 November 2020; Accepted: 2 December 2020; Published: 4 December 2020

check for updates

Simple Summary: Parasitic isopods were reported found from marine fishes from many habitat in the world. In Thailand, there is not much study on this parasitic group. This work has compiled all published parasitic isopods documents in Thailand from year 1950 to present include collecting samples from the Gulf of Thailand during the period 2006-2019. New host records were found from four species of parasitic isopods (Cymothoa eremita, Smenispa irregularis, Nerocila sundaica, Norileca triangulata) and two species of parasitic isopods (Argathona macronema, Norileca triangulata) were found first time in the central Indo-Pacific region.

\begin{abstract}
From a total of 4140 marine fishes examined, eight species of parasitic isopods were reported from marine fishes in the Gulf of Thailand. These isopods were identified in two families, Corallanidae (Argathona macronema and Argathona rhinoceros) and Cymothoidae (Cymothoa eremita, Cymothoa elegans, Smenispa irregularis, Nerocila sundaica, Norileca indica and Norileca triangulata). Most of these parasitic isopods were found in the buccal cavity of their fish hosts with one host recorded as follows: C. eremita was found from Nemipterus hexodon, C. elegans was found from Scatophagus argus, N. sundaica was found from Saurida tumbil. The majority of the isopod specimens recorded in this study was S. irregularis, which was found in the buccal cavities of five host fish, Pampus argentius, Alepes melanoptera, Caranx hippos, Parastromateus niger and Terapon jarbua, with a prevalence of $11.67 \%$, $10.43 \%, 9.78 \%, 6.10 \%$ and $4.21 \%$, respectively. Argathona rhinoceros was found in the nasal cavity and branchial cavity of Epinephelus coioides, whereas A. macronema and $N$. triangulata were found on the skin of Epinephelus coioides and Seriolina nigrofasciata, respectively. The highest species diversity was found in E. coioides, which harbored two species of parasitic isopods, A. macronema and A. rhinoceros. Cymothoa eremita, C. elegans, S. irregularis and N. triangulata were recorded for the first time in the Gulf of Thailand. The reported discovery of C. eremita, S. irregularis, N. sundaica and N. triangulata in their fish hosts were new recorded hosts. Moreover, A. macronema and N. triangulata were found for the first time in the central Indo-Pacific region.
\end{abstract}

Keywords: isopod; Argathona; Cymothoa; Smenispa; Nerocila; Norileca; Gulf of Thailand

\section{Introduction}

The order Isopoda belongs to the subphylum Crustacea, phylum Arthropoda, with more than 10,300 species found in the deepest oceans to the montane terrestrial habitats [1]. The order Isopoda comprises free-living forms that inhabit various habitats and parasitize mostly fish. Parasitic isopods are typically marine, and usually inhabit the warmer seas [2]. Isopods tend to be small, from 0.5 to $3.0 \mathrm{~cm}$ in length, and have a characteristic dorsoventrally flattened body, without a carapace [3]. Most parasitic isopods are ectoparasites, while, for example, Cryptoniscoidea was reported as an endoparasite of crustacean hosts [4]. The large groups of parasitic isopods in marine fishes are members 
of the suborder Cymothoida, superfamily Cymothooidea. Some families of this group are reported as parasites of fish, both immature forms and adults, although most of them are free-living, viz. Aegidae, Corallanidae, Cymothoidae and Gnathiidae. These parasitic isopods attach to the body surface, in the mouth or on the gills, and are sometimes found in the nasal cavities. Aegidae are distinguished from Cymothoidae by having less modified pereopods. Corallanidae are confined to tropical and subtropical regions [3]. A few corallanid isopods are parasites of fish, such as Argathona macronema, which is common in the nasal passages of serranids and lutjanids on the Great Barrier Reef [2]. Cymothoids harm the fish in several ways; mancae (larva stage) feed vocaciously and easily kill fry and fingerlings through the tissue damage they cause [2]. Permanently attached adult isopods can stunt the growth of fish and inhibit reproduction. Those in the gill chamber are usually associated with stunted gills, partly from pressure atrophy and partly from the damage associated with feeding and attachment. They have also been frequently associated with anemia. Those in the mouth affect the development of oral structures and may completely replace the tongue, as with Ceratothoa oestroides [2]. Ghani [5] stated that isopod parasites suck the blood of their fish hosts, and the fish becomes weak due to a lack of oxygen and nutrients. A weak fish is more vulnerable to various fatal diseases. Moreover, skin lesions caused by isopods are exposed to secondary bacterial infections.

Their damage to the fish culture population has been reported continuously and seems to be interesting for the study of diversity in different countries. Isopods are associated with many species of commercially important fish around the world and cause significant economic losses [6-10]. In culture systems, the isopod Alitropus typus causes high mortality such as in tilapia cage culture in Thailand, with a mortality rate of around $50-100 \%$ within $2-7$ days after initial infestation [11]. The parasitic isopod group continues to be interesting for scientists in many countries, both regarding wild and culture fish populations, for taxonomic knowledge and economic application. Most reports were in Australia [12-14], and appeared in many countries, such as in China, Colombia, India, Indonesia, New Zealand, the northern Arabian Sea, Pakistan, the Philippines and Yemen [5,12-27].

There have some reports about parasitic isopods in Thailand; the first report regarding a parasitic isopod was recorded in 1950 by Suvatti [28], and Nerocila phaeopleura, Cirolana elongata (also known as as Dolicholana elongata), Cirolana willeyi, Eurydice orientalis were reported in the Gulf of Thailand. In 1967, Pillai [19] reported the parasitic isopods Cirolana fluviatilis and Alitropus typus from Thailand. In 1968, Wichiansanka [29] studied fish lice in Songkhla lake and reported that they found three species of isopod-Rocinela belliceps, Cirolana harfordi and Excirolana chiltoni. In 1975, Wichiansanka [30] also studied the biology and distribution of fish lice in Songkhla lake and reported that they found six species of isopod-Rocinela sp., Alitropus sp., Cirolana harfordi, Excirolana chiltoni, Nerocila pigmentata and Livoneca vulgaris (was synonymized with Elthusa vulgaris). Previous parasitic isopod reports did not specify the fish host species which attach to fishes' bodies. However, reports of parasitic isopods with their fish host species were recorded after 1986 by Williams and Williams [31], Bruce and Harrison-Nelson [32], Sirikanchana [33] and Sirikanchana [34] (Table 1).

Regarding non-parasitic species of isopods, Cirolana fluviatilis, C. longistylis, Cilicaeopsis whiteleggei, Dynamenella yomsii, Paradella tomleklek and Sphaeromopsis sei were described in Phuket, Thailand [35-37].

This work focuses on surveying the parasitic isopods from the Gulf of Thailand in three areas (upper, central and lower parts) after not having had any reports regarding parasitic isopods on fishes for more than ten years. Although recently, Nerocila depressa was found to attach to the bodies of Sardinella albella from the estuary area in Thailand [38] and was reportedly found on Selar crumenophthalmus [39], that report only surveyed one small area which had an outbreak of isopods in the coastal area. The knowledge from this survey will be applied as taxonomic reference data and prophylaxis in disease management for marine fish culture in this region. 
Table 1. Parasitic isopods with their host recorded in Thailand from the literature cited.

\begin{tabular}{|c|c|c|}
\hline Parasitic Isopod & Fish Host & Reference \\
\hline Anilocra sp. & Epinephelus sp. & [34] \\
\hline Cirolana sp. & Monacanthus sp. & [34] \\
\hline $\begin{array}{c}\text { Codonophilus sp. } \\
\text { (accepted as Ceratothoa sp.) }\end{array}$ & Stolephorus indicus & [34] \\
\hline \multirow{8}{*}{ Excirolana chiltoni } & Cheilinus chlorourus & [33] \\
\hline & Kyphosus cinerascens & [33] \\
\hline & $\begin{array}{c}\text { Plectropoma maculatum } \\
\text { (accepted as Plectropomus areolatus) }\end{array}$ & [33] \\
\hline & $\begin{array}{c}\text { Plectorhynchus pictus } \\
\text { (accepted as Plectorhinchus pictus) }\end{array}$ & [33] \\
\hline & Scolopsis monogramma & [33] \\
\hline & $\begin{array}{c}\text { Siganus oramin } \\
\text { (accepted as Siganus canaliculatus) }\end{array}$ & [33] \\
\hline & $\begin{array}{c}\text { Plectropoma maculatum } \\
\text { (accepted as Plectropomus maculatus) }\end{array}$ & [34] \\
\hline & Scolopsis monogramma & [34] \\
\hline Glossogobius sp. & Parexocoetus mento & [31] \\
\hline \multirow{8}{*}{ Gnathia sp. (praniza stage) } & Cephalopholis boenak & [33] \\
\hline & $\begin{array}{c}\text { Lutianus vaigiensis } \\
\text { (accepted as Lutjanus fulvus) }\end{array}$ & [33] \\
\hline & $\begin{array}{c}\text { Scolopsis ciliatus } \\
\text { (accepted as Scolopsis ciliata) }\end{array}$ & [33] \\
\hline & Scolopsis monogramma & [33] \\
\hline & $\begin{array}{c}\text { Stethojulis phekadopleura } \\
\text { (accepted as Stethojulis trilineata) }\end{array}$ & [33] \\
\hline & Halichoeres nigrescens & [33] \\
\hline & Abudefduf saxatilis & [33] \\
\hline & Drepane punctata & [34] \\
\hline $\begin{array}{c}\text { Livoneca circularis } \\
\text { (accepted as Ryukyua circularis) }\end{array}$ & Amblygaster sirm & [31] \\
\hline $\begin{array}{l}\text { Livoneca vulgaris } \\
\text { (accepted as Elthusa vulgaris) }\end{array}$ & $\begin{array}{c}\text { Mugil dussumieri } \\
\text { (accepted as Planiliza subviridis) }\end{array}$ & [34] \\
\hline Mothocya renardi & Strongylura leiura & [31] \\
\hline \multirow{2}{*}{ Nerocila depressa } & Cyclocheilichthys apogon & [32] \\
\hline & Engraulis sp. & [32] \\
\hline Nerocilaloveni & Leiognathus sp. & [32] \\
\hline \multirow{3}{*}{ Nerocila phaiopleura } & Chirocentrus sp. & [32] \\
\hline & Sardinella fimbriata & [32] \\
\hline & Harengula sp. & [32] \\
\hline Nerocila pigmentata & Clupea spp. & [34] \\
\hline Nerocilaserra & - & [32] \\
\hline \multirow{2}{*}{ Nerocila sundaica } & Sciaena sp. & [32] \\
\hline & Mugil sp. & [32] \\
\hline
\end{tabular}




\section{Materials and Methods}

A total of 4140 marine fish specimens were collected from commercial catches (by trawl nets) and individual fishermen (by fishing rod and net) in Chonburi province $\left(13^{\circ} 20^{\prime} 18.45^{\prime \prime}, 100^{\circ} 55^{\prime} 16.18^{\prime \prime}\right.$ and $12^{\circ} 54^{\prime} 47.80^{\prime \prime}, 100^{\circ} 47^{\prime} 20.28^{\prime \prime}$ ) (upper Gulf of Thailand), Prachuap Khiri Khan province $\left(11^{\circ} 7^{\prime} 43.01^{\prime \prime}\right.$, $\left.99^{\circ} 29^{\prime} 11.23^{\prime \prime}\right)$ (central gulf of Thailand) and Surat Thani province $\left(9^{\circ} 20^{\prime} 16.04^{\prime \prime}, 99^{\circ} 40^{\prime} 52.74^{\prime \prime}\right)$ (lower Gulf of Thailand) (Figure 1) during the period 2006-2019. All fish specimens were dead and were immediately transported in a cool box to the laboratory. Host nomenclature and fish taxonomy are according to FishBase [40]. The skin, nasal cavities, mouth and branchial cavities of each fish were examined. Isopods were removed and keep in 70\% ethanol. Mouthparts and appendages of isopods were dissected for identification using the key of [13,15,25,32,41-49]. The taxonomy was updated according to the WoRMS catalogue [50].

Isopod specimens were deposited at the Zoological Museum of Kasetsart University (ZMKU). Prevalence and mean intensity were calculated according to Bush et al. [51].

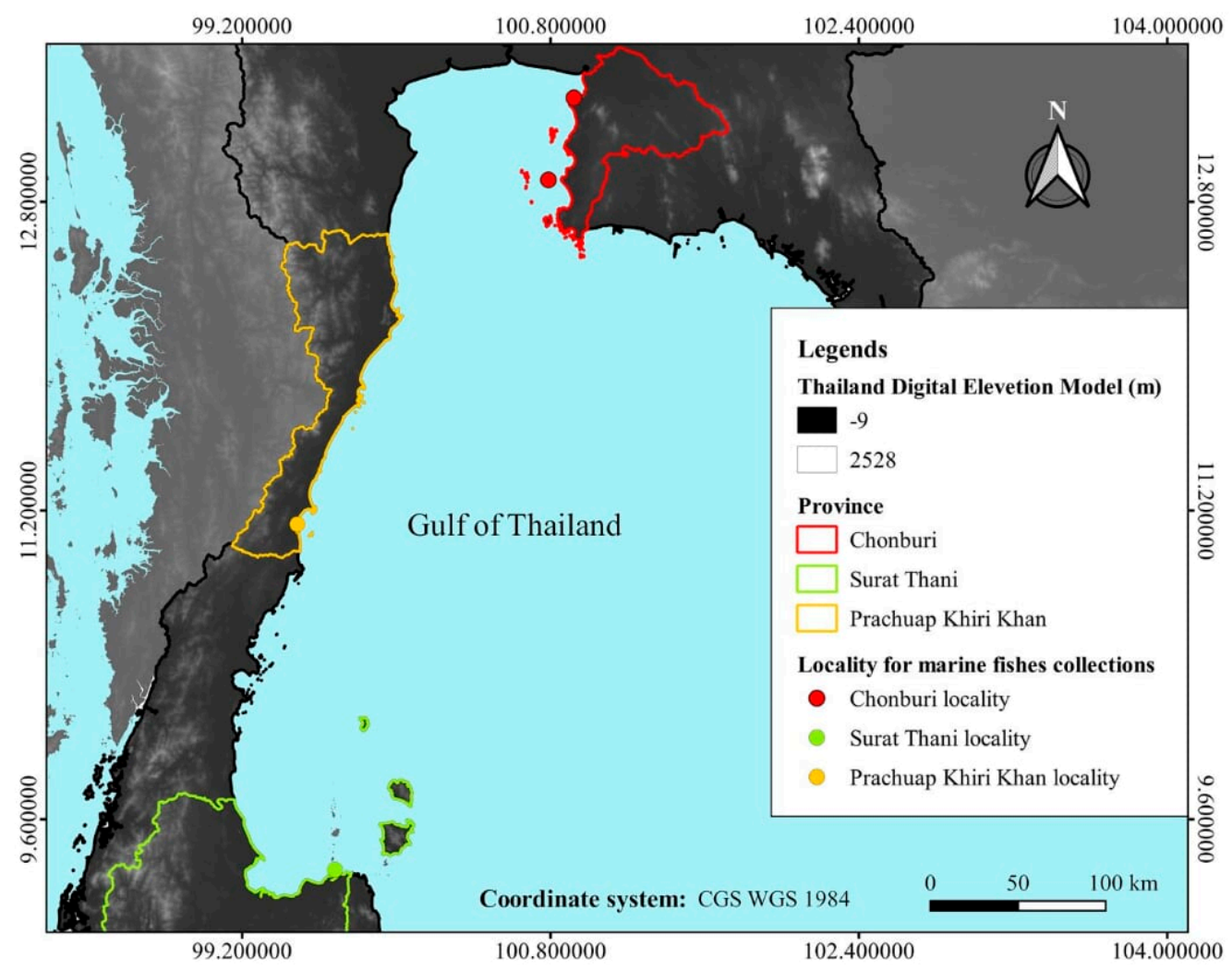

Figure 1. Map of study area in the Gulf of Thailand.

\section{Results and Discussion}

In total, 4140 marine fish specimens from 92 species (Acanthopagrus berda, Alepes melanoptera, Allenbatrachus grunniens, Anodontostoma chacunda, Arius arius, Brevitrygon imbricata, Caesio cuning, Carangoides armatus, Caranx hippos, Cephalopholis boenak, Cephalopholis formosa, Cephalopholis miniata, Cephalopholis sonnerati, Chiloscyllium punctatum, Crenimugil buchanani, Cynoglossus bilineatus, Drepane punctata, Dussumieria elopsoides, Eleutheronema tetradactylum, Ellochelon vaigiensis, Epinephelus areolatus, Epinephelus coioides, Epinephelus erythrurus, Epinephelus faveatus, Epinephelus quoyanus, Epinephelus tauvina, Euthynnus affinis, Gazza minuta, Gerres filamentosus, Gerres oyena, Hilsa kelee, Hyporhamphus quoyi, Johnius dussumieri, Lagocephalus spadiceus, Lates calcarifer, Leiognathus brevirostris, Lutjanus johnii, Lutjanus russellii, Lutjanus vitta, Monacanthus chinensis, Muraenesox bagio, Nemipterus furcosus, Nemipterus hexodon, Nibea soldado, Ophichthus rutidoderma, Otolithes ruber, Pampus argenteus, Pampus chinensis, Parachaetodon ocellatus, Parastromateus niger, Parupeneus crassilabris, Pelates quadrilineatus, Planiliza subviridis, Platax 
orbicularis, Platax teira, Platycephalus indicus, Plectorhinchus diagrammus, Plectorhinchus pictus, Plotosus canius, Plotosus lineatus, Pomadasys maculatus, Priacanthus tayenus, Psammoperca waigiensis, Psettodes erumei, Rachycentron canadum, Rastrelliger brachysoma, Rastrelliger kanagurta, Sargocentron rubrum, Saurida micropectoralis, Scatophagus argus, Scolopsis monogramma, Scomberoides lysan, Scomberomorus guttatus, Selar crumenophthalmus, Selaroides leptolepis, Seriolina nigrofasciata, Siganus canaliculatus, Siganus javus, Sillago aeolus, Sillago asiatica, Sillago indica, Sillago ingenuua, Sillago maculata, Sillago sihama, Sphyraena obtusata, Stolephorus insularis, Terapon jarbua, Terapon theraps, Trichiurus lepturus, Trypauchen vagina, Tylosurus crocodilus and Zebrias quagga) from Chonburi province (upper Gulf of Thailand), Prachuap Khiri Khan province (central gulf of Thailand) and Surat Thani province (lower Gulf of Thailand) were investigated for parasitic isopods. Seventy samples from 4140 specimens $(1.69 \%)$ were infected with adult parasitic isopods. They were identified in one suborder, two families, five genera, and eight species, which were found in 11 species of fish (Figures 2 and 3, Table 2) as follows:

Suborder Cymothoida

Family Corallanidae

Argathona macronema

Argathona rhinoceros

Family Cymothoidae

Cymothoa eremita

Cymothoa elegans

Smenispa irregularis

Nerocila sundaica

Norileca indica

Norileca triangulate

Most of the parasitic isopods from this survey were usually found in the buccal cavity of the fish host, except for Argathona rhinoceros, Argathona macronema, Norileca indica and Norileca triangulata. Only A. rhinoceros was found in nasal cavities, but in some specimens, they were attached to the branchial cavities of their fish host. A. macronema and $N$. triangulata were found on the skin of their fish host, while N. indica was found in the branchial cavities. Smenispa irregularis was found in five buccal cavities of five hosts, which can separated in three families: Carangidae (Caranx hippos, Alepes melanoptera, Parastromateus niger), Stromateidae (Pampus argentius) and Teraponidae (Terapon jarbua). Meanwhile, other isopods were found in a single host. Epinephelus coioides harbored two species of isopods, A. macronema and A. rhinoceros. The prevalence of parasitic isopods was highest in P. argentius, followed by $A$. melanoptera and C. hippos, with a prevalence of $11.67 \%, 10.43 \%$, and $9.78 \%$, respectively. All of fish in the high prevalence ranking in this study were infected with $S$. irregularis.

All fish samples were usually found to have only one member of each isopod species, except for E. coioides and C. hippos, for which two specimens were found-they had a mean prevalence of 1.10 and 1.11 individuals/fish, respectively (Table 2).

The details of the isopods found in this survey were described as follows. 

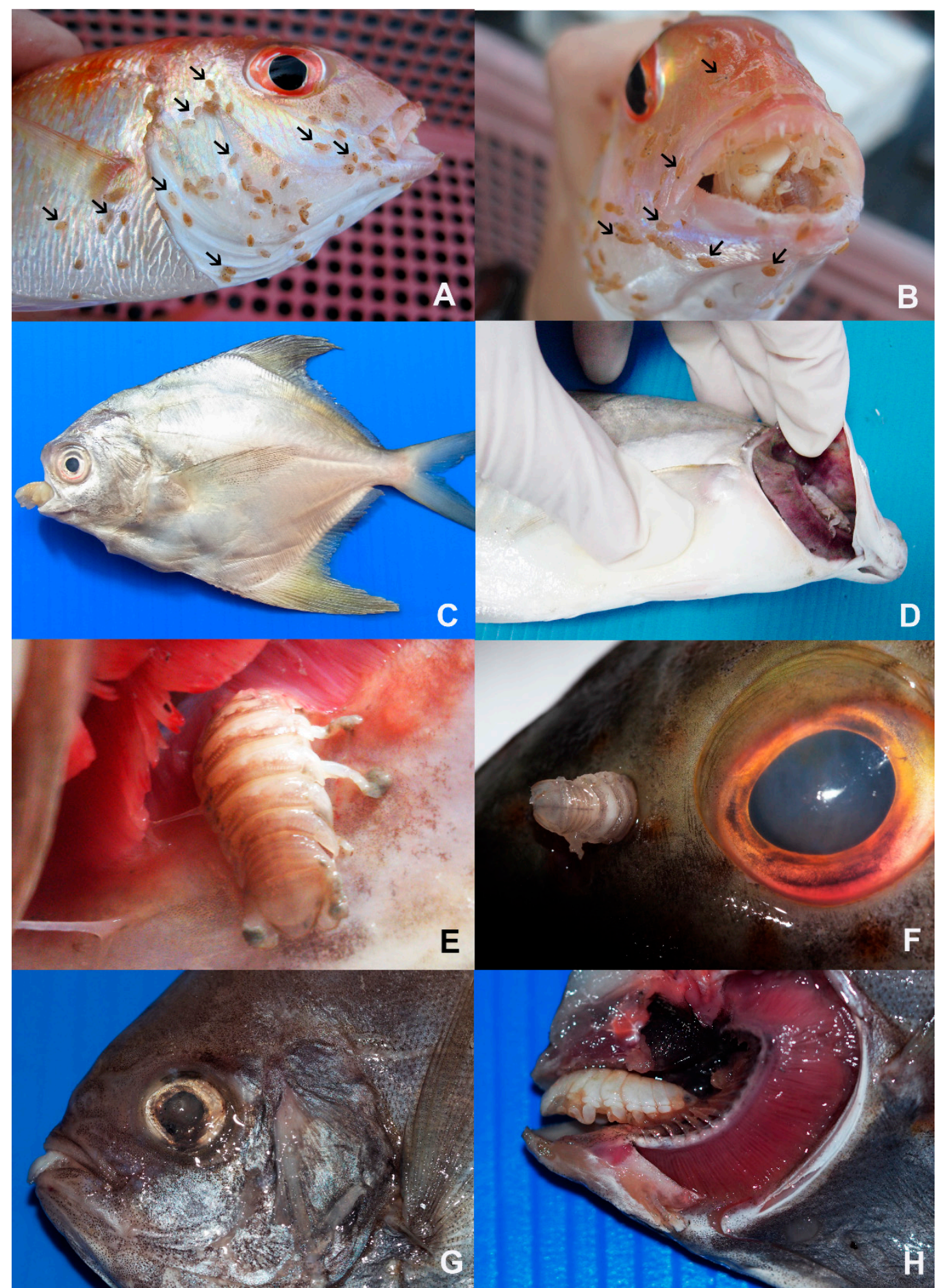

Figure 2. Various species of parasitic isopods attached to their fish host. (A,B) Cymothoa eremita in the buccal cavity of Nemipterus hexodon, many mancae (arrows) attached to same fish host. (C) Smenispa irregularis in the buccal cavity of Pampus argentius. (D) Smenispa irregularis in the gill chamber of Caranx hippos. (E) Argathona rhinoceros in the gill chamber of Epinephelus coioides. (F) Argathona rhinoceros in the nasal cavity of Epinephelus coioides. $(\mathbf{G}, \mathbf{H})$ Smenispa irregularis in the buccal cavity of Parastromateus niger, $(\mathbf{H})$ after removal of the operculum). 


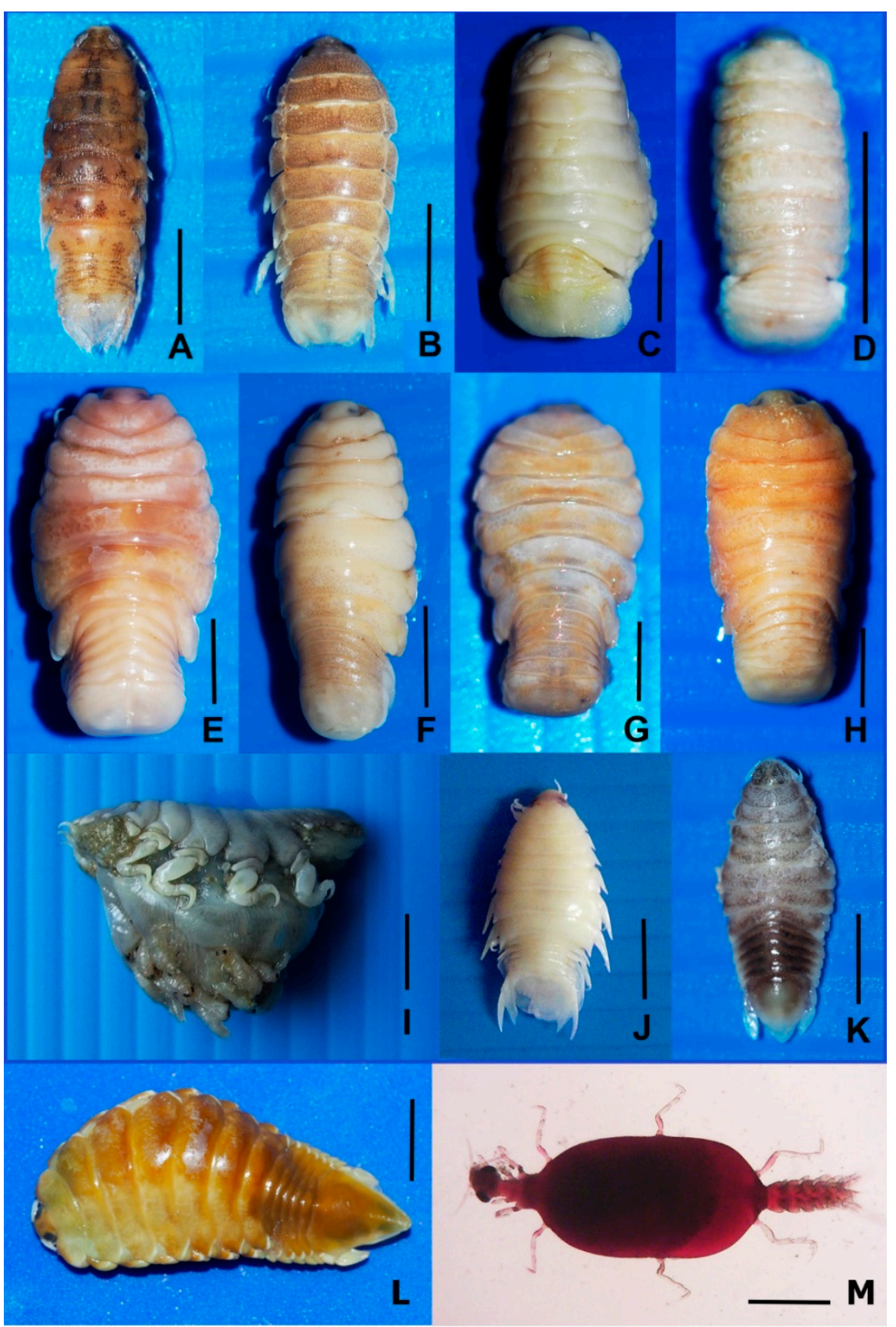

Figure 3. Parasitic isopods found in this study (A-L). scale bar $=5 \mathrm{~mm}$.). (A). Argathona macronema from Epinephelus coioides. (B). Argathona rhinoceros from Epinephelus coioides. (C). Cymothoa eremita from Nemipterus hexodon. (D). Cymothoa elegans from Scatophagus argus. (E). Smenispa irregularis from Caranx malam. (F). Smenispa irregularis from Pampus argentius. (G). Smenispa irregularis from Parastromateus niger. (H). Smenispa irregularis from Terapon jarbua. (I). Smenispa irregularis from Caranx malam, with many mancae in the brood pouch. (J). Nerocila sundaica from Saurida tumbil. (K). Norileca triangulata from Seriolina nigrofasciata. (L). Norileca indica from Selar crumenophthalmus. (M). Gnathia sp. (praniza stage) from various marine fishes species (scale bar $=0.4 \mathrm{~mm}$ ). 
Table 2. Parasitic isopod and their fish host with site of infection, prevalence $(\mathrm{P})$ and mean intensity (M.I.) from the Gulf of Thailand (in this study).

\begin{tabular}{ccccc}
\hline Parasitic Isopod & Fish Host & Site of Infection & P (\%) & M.I. \\
\hline Argathona macronema & Epinephelus coioides & skin & 1.48 & 1.00 \\
Argathona rhinoceros & Epinephelus coioides & nasal cavities/branchial cavity & 7.41 & 1.10 \\
Cymothoa eremita & Nemipterus hexodon & buccal cavity & 0.26 & 1.00 \\
Cymothoa elegans & Scatophagus argus & buccal cavity & 3.31 & 1.00 \\
\hline & Caranx hippos & buccal cavity/skin & 9.78 & 1.11 \\
& Alepes melanoptera & buccal cavity & 10.43 & 1.00 \\
Smenispa irregularis & Pampus argenteus & buccal cavity & 11.67 & 1.00 \\
& Parastromateus niger & buccal cavity & 6.10 & 1.00 \\
& Terapon jarbua & buccal cavity & 4.21 & 1.00 \\
\hline Nerocila sundaica & Saurida micropectoralis & buccal cavity & 3.08 & 1.00 \\
Norileca indica & Selar crumenophthalmus & branchial cavity & 6.67 & 1.00 \\
Norileca triangulata & Seriolina nigrofasciata & skin & 1.11 & 1.00 \\
\hline
\end{tabular}

\subsection{Family Corallanidae}

Corallanidae are a small family which are free-living or parasitic to aquatic animals, especially fish [12,46]. All two identified isopod species from the family Corallanidae found in this survey belong to genus Argathona. Argathona can be separated from other collanid genera by differences in the mouthpart morphology [12]. Argathona have a maxillule with an exopod terminating in an unguis-like point at the base of which lie one or more recurved hook-like processes, an endopod with a truncate lobe, a mandible with a narrow cutting edge, a large triarticulate palp, and a molar process is present [12]. Twelve species of Argathona are found in tropical and subtropical marine habitats throughout the Indo-Western Pacific at a depth range of 8-267 m. [46]. Fish temporarily hosting genera of Argathona included Epinephelus, Diagramma, Cromileptes, Plectopomus, Variola (Serranidae), Pseudolabras (Labridae), Lutjanus (Lutjanidae), Tetraodon (Tetraodontidae) and Muraena (Muraenidae). This genus was also found as a parasite on turtle, Chelonia [46]. Two species of Argathona, A. macronama amd A. rhinoceros, were found in this survey.

\subsection{Argathona macronema}

(syn. Aega macronema, Alcirona macronema, Argatbona macronema, Corallana macronema) [12].

The specimen of $A$. macronema has a length of $15.5 \mathrm{~mm}$, a width of $5 \mathrm{~mm}$, and was found on the skin of Epinephelus coioides, although Bruce [12] reported that they occur commonly in the nasal passages of serranids. This specimen is little bit bigger than the specimens from Australia, which have a length of $10-14.4 \mathrm{~mm}$.

A. macronema has been reported as a parasite in Epinephelus tauvina, Diagramma cinerascens, Pseudolabras sp., Trachichtodes affinis, Cromileptes altivelis, Lutjanus argentimaculatus, Lutjanus monostigma, Plectropoma maculatus, Plectropoma laevis and Plectropoma leopardus, and on the eye of areen turtle in Kenya [46,52-54].

Bruce [12] stated that this species is a common, widely spread species. It is distributed throughout the Indo-Western Pacific Ocean, including the Red Sea, Gulf of Aqaba, Gulf of Suez, Java, Celebes, New Guinea, Madagascar, Gilbert Islands, Fiji Islands, Kenya, Australia and New Caledonia [46,53]. Miers [55] reported Corallana macronema, which was the synonym of A. macronema from the Malaysian region. However, Thailand is a newly recorded geographical location for this parasite, and Epinephelus coioides is newly recordedhost.

\subsection{Argathona rhinoceros}

(syn. Livoneca nasicornis, Argatbona rhinoceros, Cymothoa rhinoceros, Gurida coelata, Argathona reidi, Alcirona pearsoni) [12]. 
Argathona rhinoceros is usually found in nasal cavities of Epinephelus coioides, and the specimen's length is $6.5-22.0 \mathrm{~mm}$, a width of $2.5-10.0 \mathrm{~mm}$, except for one sample that was found in a gill chamber (length $22.0 \mathrm{~mm}$, width $10.0 \mathrm{~mm}$ ). This species may grow to be as large as $26.0 \mathrm{~mm}$, as Bruce [12] reported from Australia. The size of this parasite retreived from nasal cavities varied according to size of the fish host.

Argathona rhinoceros has been reported as a parasite in Tetraodon leopardus, Epinephelus chlorostigma, Epinephelus tauvina, Variola louti, Epinephelus malabaricus, Epinephelus coioides, Epinephelus fuscoguttatus, Epinephelus cyanopodus and Plectropoma leopardus [46,53-55]. It is distributed throughout the Indo-Western Pacific, including Aldabra Island, the Persian Gulf, Zanzibar, Sri Lanka, India, Java, Indonesia, Thailand, Australia, the Palau Islands, Eniwetok Atoll and New Caledonia [46]. Although only two species of Argathona were reported in the Gulf of Thailand, in another region, Argathona spp. were also reported, such as A. muraenecae, which was reported as a parasite of Argyrops spinifer and Epinephelus chlorasitgma in Pakistan [5].

\subsection{Family Cymothoidae}

Isopods in this family are ectoparasites on marine, freshwater and brackish water fishes. Most of them occur in shallow water in tropical and subtropical areas [47]. The position of attachment on the host (buccal cavity, gill chamber) is usually genus- or species-specific [47]. The marine species of the order Isopoda are classified into 12 suborders, among which the suborder Cymothoida includes 29 families. Among the families of the suborder Cymothoida, superfamily Cymothooidea, the family Cymothoidae includes 43 genera [56]. Four genera were found in this study-Cymothoa, Smenispa, Nerocila and Norileca.

The genus Cymothoa was found to constitute only six species in the southwestern Indian Ocean. In Australia, it has eleven species, and in the central Indo-Pacific region it has nine species [49]. Cymothoa is mainly characterized by the general body shape, which is strongly vaulted, with widely separated antennae, a cephalon deeply immersed in pereonite 1, pereonite 7 extending past pleonite 1 , a wide pleotelson, pleonite 1 as wide as other pleonites, and uropod rami which are shorter than the pleotelson [22,49].

In this survey, two species of Cymothoa were found: C. eremita from Nemipterus hexodon and C. elegans from Scatophagus argus.

\subsection{Cymothoa eremita}

(syn. Oniscus oestrum, Oniscus eremita, Cymothoa leschenaultii, Cymothoa leaschenaultii, Cymothoa limbata, Cymothoa mathoei, Cymothoa matthaei, Cymothoa mathieui, Cymothoa edwardsii, Cymothoa edwardsi, Cymothoa erimitae, Cymothoa cinerea, Cymothoa cinerius, Cymothoa stromatei) [49].

C. eremita was found in the buccal cavity of Nemipterus hexodon, with a female length of $21.0 \mathrm{~mm}$ and a width of $10.5 \mathrm{~mm}$. In sampling time, many mancas escape from the brood pouch of the mature female and will find a new host. However, many mancas are still attached to the same host. We found them on the outer side of the operculum and also the anterior part of their host fish. Hadfield et al. [49] explained the character of C. eremita, in that they have anterolateral projections which extend to half the length of the cephalon, a truncate anterior margin of the cephalon, a pleon as wide as the pereon, uropods which do not reach the posterior margin of the pleotelson, an ischium on pereopod 7 with a bulbous protrusion and small lateral projections on the posterolateral margins of pereonite 1.

C. eremita was first collected from Madras in the mouth of Coryphaena apus [57]. Moreover, C. eremita was reported as a parasite of Parastromateus niger, Psettodes erumei, Liza vaigiensis, Peprilus paru, Pseudanthias evansi, Arothron leopardus, Tetrodon sp., Hime formosana, Hime japonica, Pampus argenteus, Pampus cinereus, Siganus canaliculatus, Plectorhinchus nigrus, Sphyraena obtusata $[44,45,49,58-60]$. The geographical distribution of this species is widely distributed in the Indo-Western Pacific region, such as Malaysia, Singapore, the Philippines, Indonesia, Australia, Thailand, Japan, China, Ceylon, the Indian Peninsula from Madras to Bombay, Mauritius, the Seychelles, Zanzibar and the Red 
Sea [43,44,60-65]. Although this species has been already reported in Thailand, Nemipterus hexodon is a new host recorded for this parasite.

\subsection{Cymothoa elegans}

C. elegans was found in the buccal cavity of Scatophagus argus. The females found in this study had a length of 14.0-15.5 mm and a width of $5.5 \mathrm{~mm}$. C. elegans is characterized by a sublime body that is more than twice as long as it is wide, with nearly parallel sides and very small eyes. The head is sunken into the chest and is wider than it is long, and has fairly short antennae, which are hidden under the head. The fifth segment is the widest. The seventh thorax is the longest and is very broad. The pleon is short and narrow, and the first segment is not hidden. It includes the telson, which is longer and wider than the leon and has posterior rounded corners. The uropods are short.

C. elegans was reportedly found on only two host fishes, Epinephelus fuscoguttatus and Scatophagus argus. The distribution of this parasite was found in Java, Indonesia and the Texas coast [43,66-68]. Therefore, the Gulf of Thailand was a new location for this parasite.

\subsection{Nerocila sundaica}

(syn. Emphylia ctenopbora, Nerocila (Emphylia) sundaica) [12].

Nerocila sundaica was found in the buccal cavity of Saurida tumbil. Females found in this study had a length of $14.0-15.5 \mathrm{~mm}$ and a width of $5.5 \mathrm{~mm}$. Nerocila is a large genus of the family Cymothoidae including at least 65 species living attached to the skin or on the fins of fishes [7]. Nerocila usually have pleonites 1 and 2 with ventrolateral processes, and uropods extending beyond the posterior of pleotelson [24]. Bowman [69] explained the character of N. sundaica that have a narrow head. Basal segments of antennae 1 are inflated, and are close to or in contact with one another medially. Distal segments of pereopods 3, 6 and 7 are armed with strong spines on grasping margins. Pereopods 1, 2, 4 and 5 do not have marginal spines, and the dactyls are strongly developed, with that of pereopod 4 being the largest.

Nerocila sundaica was recorded on Scatophagus argus, Pseudosciaena polyactis, Sciaena sp., Eleutheronema sp., Mugil sp., Otolithes ruber, Therapon jarbua, Engraulis mystax, Serranus gilberti, Pellona indica, Sardinella fimbriata, Carangoides malabaricus, and Ilisha melastoma [12,15,55,69-71]. The geographical distribution of N. sundaica is the Persian Gulf, the Bay of Bengal, the Indian Ocean and the northern part of the South China Sea, the Java Sea, the Malaysian region, China, the south coast of Hong Kong, Singapore, the Red Sea and the northern Indian Ocean [12,15,55,69,70,72,73].

\subsection{Norileca indica}

(syn. Livoneca indica, Livoneca ornata, Lironeca indica) [14].

Norileca indica was found in the branchial cavity of Selar crumenophthalmus. Females found in this study had a length of 2.4-2.9 mm and a width of 1.8-2.2 $\mathrm{mm}$. The body of the parasite twists to one side. The characteristics of genus Norileca include pleonites 1 and 2 without ventrolateral processes, and uropods not extending beyond the posterior of pleotelson [14,24]. Pleonite 5 and pleonite 1 are subequal, while pleonite 5 is narrower than pleonite 1 in $N$. triangulate. Uropods are two-thirds the length of pleotelson [14,24].

In Thailand, this parasitic isopod was reported only in Selar crumenophthalmus [38,72]. N. indica was reportedly found in Alepes apercna, Carangoides malabaricus, Decapterus russelli, Herklotichthyes sp., Nemipterus randalli, Rastrelliger kanagurta, Secutor insidiator, Selar crumenophthalmus [5,14,23,39,42,74-80]. These isopods are distributed in the Australia-New Zealand region, the Bay of Bengal, India, Malaysia, Mozambique, Pakistan, the Philippines and Thailand [5,14,23,39,43,74-80].

\subsection{Norileca triangulata}

(syn. Livoneca triangulata) [14]. 
The special characterisitcs of $N$. triangulata include pleonite 5 being manifestly narrower than pleonite 1, and maxilliped palp article 2 being about as long as article 3 [14]. In our study, we found only one female specimen of $N$. triangulata attached to the skin of Seriolina nigrofasciata. This female isopod has a length of $15.0 \mathrm{~mm}$ and a width of $6.0 \mathrm{~mm}$.

N. triangulata was reported found in Rastrelliger kanagurta, Sardinella gibbosa, Parexocoetus brachypterus. This species is distributed aorung Tanimdao Island, the Philippines, Australia and the southeast coast of India $[5,14,17,24,81]$. The Gulf of Thailand is a new geographical record for this parasite and Epinephelus coioides is a newly recorded host.

\subsection{Smenispa irregularis}

(syn. Cymothoa irregularis, Cymothoa paradoxa, Enispa irregularis) [14,82].

S. irregularis was found in five species of fish, Caranx hippos, Caranx malam, Pampus argentius, Parastromateus niger and Terapon jarbua, in this study. Most of them were found in the buccal cavity of their fish host. Females found in this study had a length of $16.0-22.5 \mathrm{~mm}$ and a width of $8.0-12.0 \mathrm{~mm}$. Martin et al. [82] stated that the diagnostic characteristics of the genus are the strongly vaulted body, a cephalon embedded in pereonite 1, antennula shorter than the antenna, bases set wide apart, the pereon and pleon being co-linear with the sub-parallel lateral margins, pereopods lacking carina on the bases, and the endopods of pleopods $3-5$ having large folds. The size of the ovigerous female in our study seems to be smaller when compared with Martin et al. [82] (20-24 mm).

Previously, E. irregularis had only two host records, Psettodes erumei and Caranx carangus [14]. Recently, Martin et al. [82] changed the nomenclatural from Enispa irregularis to Smenispa irregularis, and reported the host as Acanthopagrus latus (Sparidae) from Western Australia. However, Miers [55] stated that Cymothoa irregularis is common on fishes in the seas of Amboina, Malaysia. Moreover, Martin et al. [82] noted that Smenispa irregularis is known to occur on host species from the families Sparidae, Carangidae, and Psettodidae, suggesting the species has low host specificity. E. irregularis's distribution included Ambon Island, Arafura Sea, Atlantic coast of Panama, Carnarvon, Jakarta Bay, Northern Territory, Singapore, Thailand and Western Australia [14,42,70,82-84].

Caranx hippos, Alepes melanoptera, Pampus argentius, Parastromateus niger and Terapon jarbua were new host records of E. irregularis.

In this survey, we did not find Livoneca sp., although this genus has been recorded in Thailand for a long time. Smit et al. [85] stated that of the approximately 60 species that had been placed in Livoneca up to 1990, most were relocated to Elthusa and Ichthyoxenus, with only three species now remaining in the genus [14]. From our results, two species of parasitic isopods previously had their genus as Livoneca but changed to another genus-Argathona rhinoceros (syn. Livoneca nasicornis) and Norileca triangulata (syn. Livoneca triangulata).

The size of the parasitic isopods on their host in this study in some specimens was not in same range as the literature cited, such as A. macronema and S. irregularis. This can explained by the study by Leonardos and Trilles [86], who studied host-parasite relationships between parasitic isopod Mothocya epimerica on sand smelt Atherina boyeri and found that parasite size increased with host size. The prevalence of isopod infections from this study was only the guideline for advance research because we randomised the marine fish specimens discontinuously, because the prevalence of parasites varied according to the month, and the sex and size of hosts [87].

Low host specificity for parasitic isopod to their fish hosts was also confirmed. The parasitic isopods in each fish species from the literature cited seem to be different from this study. For example, Caranx hippos from the Caribbean area was found to harbour Cymothoa oestrum inside the mouth [47]. Parastromateus niger was found to harbour Cymothoa eremita [57]. Pampus argenteus was found to harbour Cymothoa eremita [23,49]. For only two hosts, A. rhinoceros was found in the nasal cavities of Epinephelus coioides, which is the same as the report in New Calidonia [53], and Scatophagus argus hosted the parasitic isopod Cymothoa elegans, which is the same as the report in Indonesia [67]. 
The effects of parasitic isopods on their fish hosts have been explained in many records. However, in most cases, the mean intensity is usually only one isopod per infected fish. In this case, infection in low prevalence in a fish population does not seem to affect the economy. However, in some cases, they can change fish behavior, anatomy, or morphology [88]. The swimming capacity of the fish was also found to be affected by parasitic isopods [89]. For instance, Cymothoa exigua sucks so much blood from its host fish's tongue that the tongue atrophies and is destroyed and the isopod remains attached to the remaining tongue stub and is used by the host as a replacement tongue for food manipulation [90]. Although many parasitic isopods feed on fish blood, there are some exceptions, such as Argathona macronema, which feeds on fish mucus, not blood [8]. The low mean intensity with low prevalence seems to not be a danger for marine aquaculture, but the isopod population can increase their number rapidly if this habitat has a high population of fish hosts, such as a fish culture system. They affect fish growth and production, causing economic losses.

Lester [2] explained the life cycle of an isopod of a gravid female which releases eggs into a brood pouch. The eggs embryonate, hatch and undergo two or more moults to form manca or pullus II stage. In this study, some isopod specimens of S. irregularis were found as many mancae from the brood pouch of a gravid female (Figure 2). The post-mancal juvenile stages (sometimes referred to as the aegathoid stage) have only six pairs of legs, large compound eyes, and highly setose pleopods for active swimming. The juveniles will attach themselves to a convenient fish host and eventually attach to the preferred host-species [46]. After a short free-swimming period, they are parasitic and need to find a fish to take their first meal within one to two days or they will die. From this survey, we found that a specimen of Nemipterus hexodon was attached with many mancae (Figure 2A,B), and this fish specimen had the isopod Cymothoa eremita in its mouth (Figure 2A,B). This finding seems to correspond with that of Lester [2], as in the tongue biters group such as Ceratothoa spp., the mancae move to the preferred site and remain attached to the fish.

In the cymothoids group, they have a short free-living planktonic phase and then attach to fish hosts. Heavy infestations of parasitic juveniles have the potential to kill small fingerlings. So, in a culture system, prevention may done by eradicate immature forms of isopod when they are planktonic [11].

Other than the data regarding the abundance of parasitic isopods in Thailand as seen in the literature review above, the areas which connect to the Gulf of Thailand that have parasitic isopod reports, such as the Malaysian region [55] and the South China Sea [15], were compared with the results of the parasitic survey in this study to discuss the new geographical record of isopod parasites in this region.

Smit et al. [85] mapped the distribution of the marine cymothoids using Spalding et al. [91], and they found that the highest diversity resides within the tropical regions of the central Indo-Pacific, with 79 marine Cymothoidae isopods. Comparing this with our data, all parasitic isopods that we found in the survey were already recored in the central Indo-Pacific region, except for Norileca triangulata, which was distributed around Tanimdao Island, the Philippines, Australia and southeast coast of India.

\section{Conclusions}

The survey found eight species of parasitic isopod-Argathona macronema, Argathona rhinoceros, Cymothoa eremita, Cymothoa elegans, Nerocila sundaica, Norileca indica, Norileca triangulata and Smenispa irregularis. Nine new host records of five parasites were also reported, Argathona macronema from host Epinephelus coioides, Cymothoa eremita from host Nemipterus hexodon, Cymothoa elegans from host Scatophagus argus, Nerocila sundaica from host Saurida tumbil, Norileca triangulata from host Seriolina nigrofasciata and Smenispa irregularis from Alepes melanoptera, Caranx hippos, Pampus argentius, Parastromateus niger and Terapon jarbua. However, in this study, the praniza stage of isopod Gnathia spp. (family Gnathiidae) (Figure 3M) was also found in 15 species of fishes (Cephalopholis formosa, Cephalopholis miniata, Cephalopholis sonnerati, Epinephelus areolatus, Epinephelus coioides, Epinephelus 
erythrurus, Epinephelus quoyanus, Lutjanus johnii, Lutjanus russellii, Pelates quadrilineatus, Plectorhynchus pictus, Scatophagus argus, Seriolina nigrofasciata, Sillago aeolus and Sillago sihama).

Argathona macronema, Cymothoa eremita, Cymothoa elegans and Norileca triangulata were newly recorded in Thailand. According to Spalding et al. [91], Norileca triangulata was found for the first time in the central Indo-Pacific region.

Author Contributions: Conceptualization, W.P.; methodology, W.P.; validation, W.P. and A.S.; investigation, W.P. and A.S.; resources, W.P.; specimen curation, W.P. and A.S.; data curation, W.P. and A.S.; writing-original draft preparation, W.P. and A.S.; writing — review and editing, W.P.; visualization, W.P.; funding acquisition, W.P. All authors have read and agreed to the published version of the manuscript.

Funding: This research was funded by Kasetsart University Research and Development Institute (KURDI).

Acknowledgments: This work was supported by Department of Zoology and International SciKU Branding (ISB), Faculty of Science, Kasetsart University. We also thank to all research assistants who helped for survey and collected Isopod samples from Chonburi, Prachuap Khiri Khan and Surat Thani province. We would like to thank the editor and reviewers for their valuable comments and suggestions on our manuscript. This research was approved by the Institutional Animal Care and Use Committee, Faculty of Science, Kasetsart University, Thailand under project number ACKU61-SCI-019.

Conflicts of Interest: The authors declare no conflict of interest.

\section{References}

1. Wilson, G.D.F. Global diversity of Isopod crustaceans (Crustacea; Isopoda) in freshwater. Hydrobiologia 2008, 595, 231-240. [CrossRef]

2. Lester, R.J.G. Crustacean parasites. In Marine Parasitology; Rohde, K., Ed.; CSIRO Publishing: Melbourne, Australia, 2005; pp. 138-144.

3. Montelli, L.; Lewis, J. Survey of Biofouling on Australian Navy Ships: Crustacea; Isopoda and Amphipoda Caprellidea; Maritime Platforms Division Defence Scienceand Technology Organisation: Australia, 2008. Available online: https://www.semanticscholar.org/paper/Survey-of-Biofouling-on-Australian-Navy-Ships\%3A-\%3B-\%3B-Montelli/d41e648e6d1591038afbab23fb88e26c35209cbb (accessed on 6 July 2017).

4. Williams, J.D.; Boyko, C.B. The global diversity of parasitic Isopods associated with crustacean hosts (Isopoda: Bopyroidea and Cryptoniscoidea). PLoS ONE 2012, 7, e35350. [CrossRef]

5. Ghani, N. Isopod parasites of marine fishes of Pakistan. Proc. Pak. Congr. Zool. 2003, 23, 217-221.

6. Ravichandran, S.; Rameshkumar, G.; Trilles, J.P. New records of two parasitic cymothoids from Indian fishes. J. Parasit. Dis. 2011, 35, 232-234. [CrossRef]

7. Bharadhirajan, P.; Murugan, S.; Sakthivel, A.; Selvakumar, P. Isopods parasites infection on commercial fishes of Parangipettai waters, southeast coast of India. Asian Pac. J. Trop. Dis. 2014, 4, S268-S272. [CrossRef]

8. Poore, G.C.B.; Bruce, N.L. Global Diversity of Marine Isopods (Except Asellota and Crustacean Symbionts). PLoS ONE 2012, 7, e43529. [CrossRef]

9. Hutson, K.S.; Catalano, S.R.; Whittington, I.D. Metazoan Parasite Survey of Selected Macro-Inshore Fish of Southeastern Australia, Including Species of Commercial Importance; James Cook University: Townsville, Australia, 2011; p. 259

10. Leong, T.S.; Wong, S.Y. Parasite Fauna of Seabass, Lates calcarifer Bloch, Imported from Thailand and Those Cultured in Floating Cages in Penang, Malaysia. In The First Asian Fisheries Forum; Maclean, J.L., Dizon, L.B., Hosillos, L.V., Eds.; Asian Fisheries Society: Manila, Philippines, 1986; pp. 251-254.

11. Chinabut, S. A case study of isopod infestation in tilapia cage culture in Thailand. FAO Fish. Tech. Pap. Issue 2002, 406, 201-202.

12. Bruce, N.L. Species of Argathona Stebbing, 1905 (Isopoda, Corrallanidae) new to Australia, with description of two new species. Crustaceana 1982, 42, 12-25. [CrossRef]

13. Bruce, N.L. Australian species of Nerocila Leach, 1818, and Creniola n.gen. (Isopoda: Cymothoidae), crustacean parasites of marine fishes. Rec. Aust. Mus. 1987, 39, 355-412. [CrossRef]

14. Bruce, N.L. The genera Catoessa, Elthusa, Enispa, Ichthyoxenus, Idusa, Livoneca and Norileca n.gen. (Isopoda, Cymothoidae), crustacean parasites of marine fishes, with descriptions of eastern Australian species. Rec. Aust. Mus. 1990, 42, 247-300. [CrossRef] 
15. Yu, H.; Li, X. Further report of the Flabellifera of Hainan Island, South China Sea. Studia Mar. Sin. 2003, 45, 260-272.

16. Williams, E.H., Jr.; Bunkley-Williams, L.; Sanner, C.J. New host and locality records for Copepod and Isopod parasites of Colombian marine fishes. J. Aquat. Anim. Health 1994, 6, 362-364. [CrossRef]

17. Rameshkumar, G.; Ravichandran, S. First occurrence of Norileca triangulata (Crustacea: Isopoda: Cymothoidae) from Indian marine fishes. J. Parasit. Dis. 2015, 39, 33-36. [CrossRef]

18. Kensley, B. Biogeography of the marine Isopoda of the Indian Ocean, with a check-list of species and records. Isopod systematics and evolution. Crustacean 2001, 13, 205-264.

19. Pillai, N.K. Littoral and parasitic isopods from Kerala: Families Eurydicidae, Corallanidae and Aegidae. J. Bombay Nat. Hist. Soc. 1967, 64, 267-283.

20. Rameshkumar, G.; Ravichandran, S.; Sivasubramanian, K. Invasion of parasitic isopods in marine fishes. J. Coast. Life Med. 2013, 1, 88-94.

21. Ranjitsingh, A.J.A.; Padmalatha, C. Parasitic infestation on commercially important sardines. Curr. Sci. 1997, 72, 171.

22. Rameshkumar, G.; Ramesh, M.; Ravichandran, S.; Trilles, J.P.; Shobana, C. Nerocila sundaica (Isopoda, Cymothoidae) parasitizing Otolithes ruber from Nagapattinam, Southeast coast of India. J. Parasit. Dis. 2015, 39, 789-792. [CrossRef]

23. Rameshkumar, G.; Ravichandran, S.; Ramesh, M. Distribution of isopod parasites in Carangid fishes from Parangipettai, Southeast coast of India. J. Parasit. Dis. 2016, 40, 124-128. [CrossRef]

24. Kazmi, Q.B.; Schotte, M.; Yousuf, F. An illustrated key to the Malacostraca (Crustacea) of the Northern Arabian Sea part-V: Isopoda. Pak. J. Mar. Sci. 2002, 11, 47-116.

25. Arthur, J.R.; Lumanlan-Mayo, S. Checklist of the parasites of fishes of the Philippines. FAO Fish. Tech. Pap. $1997,369,102$.

26. Bruce, N.L. The Marine Fauna of New Zealand: Isopoda, Aegidae (Crustacea); NIWA National Institute of Water and Atmospheric Research Ltd.: Auckland, New Zealand, 2009.

27. Yuniar, A.T.; Palm, H.W.; Walter, T. Crustacean fish parasites from Segara Anakan Lagoon, Java, Indonesia. Parasitol. Res. 2007, 100, 1193-1204. [CrossRef] [PubMed]

28. Suvatti, C. Fauna of Thailand; Department of Fisheries: Bangkok, Thailand, 1950; pp. 130-132.

29. Wichiansanka, S. Observation on the Fish Louse of Songkhla lake. In Annual Report of the Songkhla Marine Fisheries Station; Department of Fisheries: Bangkok, Thailand, 1968.

30. Wichiansanka, S. A Preliminary Study on Biology and Distribution of Fish Lice in Songkhla Lake. Master's Thesis, Kasetsart University, Bangkok, Thailand, 1975.

31. Williams, L.B.; Williams, E.H. Some parasite isopods (Crustacea: Cymothoidae) of marine fish from Thailand. Galaxca 1986, 5, 213-216.

32. Bruce, N.L.; Harrison-Nelson, E.B. New records of fish parasitic marine isopod crustaceans (Cymothoidae, subfamily Anilocrinae) from the indo-west Pacific. Proc. Biol. Soc. Wash. 1988, 101, 585-602.

33. Sirikanchana, P. Parasites of Coral Fishes; Kasetsart University: Bangkok, Thailand, 1986.

34. Sirikanchana, P. Parasites of Aquatic Animal, 6th ed.; Sky Word Advertising Ltd.: Bangkok, Thailand, 2003.

35. Bruce, N.L.; Olesen, J. Cirolanid isopods from the Andaman Sea off Phuket, Thailand, with description of two new species. Phuket Mar. Biol. Cent. Spec. Publ. 2002, 23, 109-131.

36. Schotte, M.; Kensley, B. New species and records of Flabellifera from the Indian Ocean (Crustacea: Peracarida: Isopoda). J. Nat. Hist. 2005, 39, 1211-1282. [CrossRef]

37. Storey, M. New species and a new record of sphaeromatid isopods (Crustacea) from the Andaman Sea, Thailand. Phuket Mar. Biol. Cent. Spec. Publ. 2002, 23, 133-148.

38. Printrakoon, C.; Purivirojkul, W. Prevalence of Nerocila depressa (Isopoda, Cymothoidae) on Sardinella albella from a Thai estuary. J. Sea Res. 2011, 65, 322-326. [CrossRef]

39. Intamong, J.; Kaewviyudth, S. Occurrence of Parasitic Isopods Norileca indica on Some Carangid Fishes from the Upper Gulf of Thailand. In Proceedings of the 4th Marine Science Conference, Blue Ocean Science, Songkhla, Thailand, 10-12 June 2014.

40. Froese, R.; Pauly, D.; FishBase. World Wide Web Electronic Publication. 2019. Available online: www. fishbase.org (accessed on 5 November 2020).

41. Nierstrasz, H.F. Die Isopoden-Sammlung im Naturhistorischen Reichsmuseum zu Leiden.-1. Cymothoidae. Zoologische Mededeelingen. Rijksmus. Van. Nat. Hist. Leiden 1915, 1, 71-108. 
42. Trilles, J.P. Les Cymothoidae (Isopoda, Flabellifera) des collections du MuséumNational d'Histoire Naturelle de Paris. IV. Les Lironecinae Schioedte \& Meinert, 1884. Bull. Mus. Natl. Hist. Nat. Paris 3ème Série 390 Zool. 1976, 272, 773-800.

43. Trilles, J.P. Les Cymothoidae (Isopoda, Flabellifera; parasites des poissons) du Rijksmuseum van Natuurlijke Historie de Leiden. II. Afrique, Amérique et régions Indo-ouest-Pacifiques. Zool. Med. Leiden. 1979, 54, 245-275.

44. Brusca, R.C. A monograph on the Isopoda Cymothoidae (Crustacea) of the eastern Pacific. Zool. J. Linn. Soc. 1981, 73, 117-199. [CrossRef]

45. Bowman, T.E.; Tareen, I.U. Cymothoidae from fishes of Kuwait (Arabian Gulf) (Crustacea: Isopoda). Smithson. Contrib. Zool. 1983, 382, 1-30. [CrossRef]

46. Delaney, P.M. Phylogeny and biogeography of the marine isopod family Corallanidae (Crustacea, Isopoda, Flabellifera). Contrib. Sci. Nat. Hist. Mus. Los Angeles Cty. 1989, 409, 1-75.

47. Kensley, B.; Schotte, M. Guide to the Marine Isopod Crustaceans of the Caribbean; Smithsonian institution Press: Washington, DC, USA; London, UK, 1989.

48. Thatcher, V.E.; Loyola e Silva, J.d.; Jost, G.F.; Souza-Conceição, J.M. Comparative morphology of Cymothoa spp. (Isopoda, Cymothoidae) from Brazilian fishes, with the description of Cymothoa catarinensis sp. nov. and redescriptions of C. elegans Perty and C. oestrum (Linnaeus). Rev. Bras. Zool. 2003, 20, 541-552. [CrossRef]

49. Hadfield, K.; Bruce, N.L.; Smit, N.J. Review of the fish-parasitic genus Cymothoa Fabricius, 1793 (Isopoda, Cymothoidae, Crustacea) from the southwestern Indian Ocean, including a new species from South Africa. Zootaxa 2013, 3640, 152-176. [CrossRef]

50. WoRMS Editorial Board. World Register of Marine Species. Available online: http://www.marinespecies.org (accessed on 9 November 2020).

51. Bush, A.O.; Lafferty, K.D.; Lotz, J.M.; Shostak, A.W. Parasitology meets ecology on its own terms: Margolis et al. revisited. J. Parasitol. 1997, 83, 575-583. [CrossRef]

52. Monod, T. Sur un Argathona (Crustacea, Isopoda) de Kenya. Bull. Mus. Natl. Hist. Nat. Paris 1975, 226, 999-1004.

53. Justine, J.-L.; Beveridge, I.; Boxshall, G.A.; Bray, R.A.; Moravec, F.; Trilles, J.-P.; Whittington, I.D. An annotated list of parasites (Isopoda, Copepoda, Monogenea, Digenea, Cestoda and Nematoda) collected in groupers (Serranidae, Epinephelinae) in New Caledonia emphasizes parasite biodiversity in coral reef fish. Folia Parasitol. 2010, 57, 237-262. [CrossRef]

54. Justine, J.-L.; Beveridge, I.; Boxshall, G.A.; Bray, R.A.; Miller, T.L.; Moravec, F.; Trilles, J.P.; Whittington, I.D. An annotated list of fish parasites (Isopoda, Copepoda, Monogenea, Digenea, Cestoda, Nematoda) collected from Snappers and Bream (Lutjanidae, Nemipteridae, Caesionidae) in New Caledonia confirms high parasite biodiversity on coral reef fish. Aquat. Biosyst. 2012, 8, 1-29. [CrossRef]

55. Miers, E.J. On a collection of Crustacea from the Malaysian Region.Part IV. Penaeidae, Stomatopoda, Isopoda, Suctoria and Xiphosura. Ann. Mag. Nat. Hist. 1880, 5, 457-467. [CrossRef]

56. Boyko, C.B.; Bruce, N.L.; Hadfield, K.A.; Merrin, K.L.; Ota, Y.; Poore, G.C.B.; Taiti, S.; Schotte, M.; Wilson, G.D.F. World Marine, Freshwater and Terrestrial Isopod Crustaceans database. Cymothoidae Leach, 1818. Accessed through: World Register of Marine Species. Available online: http://www.marinespecies.org/aphia.php (accessed on 5 November 2020).

57. Kumar, G.R.; Ravichandran, S.; Trilles, J.P. Observation on an isopod parasitizing the edible fish Parastromateus niger in the Parangipettai coast of India. J. Environ. Biol. 2012, 33, 191-193. [PubMed]

58. Justine, J.-L.; Beveridge, I.; Boxshall, G.A.; Bray, R.A.; Moravec, F.; Whittington, I.D. An annotated list of fish parasites (Copepoda, Monogenea, Digenea, Cestoda and Nematoda) collected from Emperors and Emperor Bream (Lethrinidae) in New Caledonia further highlights parasite biodiversity estimates on coral reef fish. Zootaxa 2010, 2691, 1-40. [CrossRef]

59. Kumar, A.A.; Rameshkumar, G.; Ravichandran, S.; Priya, E.R.; Nagarajan, R.; Leng, A.G.K. Occurrence of cymothoid isopod from Miri, East Malaysian marine fishes. J. Parasit. Dis. 2015, 39, 206-210. [CrossRef] [PubMed]

60. Radhakrishnan, N.; Nair, N.B. Nature of crustacean infestation of fishes along the Southwest coast of India. Aeta. Incti. Et-Pise. 1983, 13, 93-115. 
61. Williams, E.H.; Bunkley-Williams, L. Checklists of the parasites of dolphin, Coryphaena hippurus, and pompano dolphin, C. equiselis with new records, corrections, and comments on the literature. Rev. Fish. Sci. 2010, 18, 73-93. [CrossRef]

62. Stebbing, T.R.R. Isopoda from the Indian Ocean and British East Africa. No. 6. In: Percy Sladen Trust Expedition to the Indian Ocean in 1905. Trans. Linn. Soc. Lond. Zool. 1910, 2, 83-122. [CrossRef]

63. Stebbing, T.R.R. The Percy Sladen Trust Expedition to the Indian Ocean in 1905, under the leadership of Mr J. Stanley Gardiner. Isopoda from the Indian Ocean and British East Africa. Trans. Linn. Soc. Lond. Zool. 1910, 14, 83-122. [CrossRef]

64. Monod, T. On a few isopods from Ceylon. Spolia Zeylan. 1924, 13, 97-101.

65. Monod, T. Tanaidacea et Isopoda. Mission Robert Ph. Dollfus en Egypte. Mem. Inst. Egypte 1933, 21, 161-264.

66. Rückert, S. Marine Fischparasiten in Indonesien: Befallssituation und Bedeutung für die Marikultur von Zackenbarschen; Heinrich-Heine-Universität: Düsseldorf, Germany, 2006.

67. Kleinertz, S. Fischparasiten als Bioindikatoren: Zum Umweltstatus von Kustenokosystemen und Einer Zackenbarschmarikultur in Indonesien; Universitat Bremen: Bremen, Germany, 2010.

68. Cook, C.W. The Early Life History and Reproductive Biology of Cymothoa Elegans, a Marine Isopod Parasitizing Atlantic Croaker, (Micropogonias Undulatus), Along the Texas Coast. Master's Thesis, The University of Texas at Austin, Austin, TX, USA, 2012.

69. Bowman, T.E. Restoration of the subgenus Emphylia Koelbel for the parasitic isopod Nerocila sundaica Bleeker (Flabellifera, Cymothoidae). Crustaceana 1978, 34, 33-44. [CrossRef]

70. Bleeker, P. Recherches sur les Crustacés de L'Inde Archipelagique. II. Sur les Isopodes Cymothoadiens de L' Archipel Indien. Natuurkundige vereeniging in Nederlandsche-Indie, Batavia. Verhandelingen 1857, 2, $20-42$.

71. Chidambaram, K.; Menton, M.D. The isopod parasite Nerocila sundaica on west coast food fishes. Curr. Sci. 1945, 14, 308.

72. Barnard, K.H. Isopods collected by the RIMS 'Investigator'. Rec. Indian Mus. 1936, 38, 147-191.

73. Trilles, J.P.; Rameshkumar, G.; Ravichandran, S. Nerocila species (Crustacea, Isopoda, Cymothoidae) from Indian marine fishes. Parasitol. Res. 2013, 112, 1273-1286. [CrossRef]

74. Nagasawa, K.; Petchsupa, N. Norileca indica (Isopod, Cymothoidae) Parasitic on Bigeye Scad Selar crumenophthalmus in Thailand. Biogeography 2009, 11, 131-133.

75. Kottarathil, H.A.; Sahadevan, A.V.; Kattamballi, R.; Kappalli, S. Norileca indica (Crustacea: Isopoda, Cymothoidae) infects Rastrelliger kanagurta along the Malabar Coast of India-Seasonal variation in the prevalence and aspects of host-parasite interactions. Zool. Stud. 2019, 58, 35.

76. Kumar, A.A.; Rameshkumar, G.; Ravichandran, S.; Nagarajan, R.; Prabakaran, K.; Ramesh, M. Distribution of isopod parasites in commercially important marine fishes of the Miri coast, East Malaysia. J. Parasit. Dis. 2017, 41, 55-61. [CrossRef]

77. Dipanjan, R.; Santanu, M.; Anil, M. First report of parasitic isopod Norileca indica Milne-Edwards, 1840 from Northern part of East Coast of India. Int. J. Exp. Res. Rev. 2016, 4, 19-25.

78. Cruz-Lacierda, E.R.; Nagasawa, K. First record of Norileca indica (Isopoda, Cymothoidae) parasitic on Selar crumenophthalmus and Decapterus kurroides (Perciformes, Carangidae) in the Philippines. Comp. Parasitol. 2017, 84, 60-63. [CrossRef]

79. Van der Wal, S.; Smit, N.J.; Hadfield, K.A. Redescription and molecular characterisation of the fish parasitic isopod Norileca indica (Milne Edwards, 1840) (Crustacea: Isopoda: Cymothoidae) with a key to the genus. Afr. Zool. 2017, 52, 163-175. [CrossRef]

80. Avdeev, V.V. Notes on the distribution of the marine Cymothoidae (Isopoda, Crustacea) in the Australian-New Zealand region. Folia Parasit. 1978, 25, 281-283.

81. Ghani, N.; Ali, Q.M. Two representatives of parasitic Isopods. Catoessa ambassae Bruce 1990 and Norileca triangulata Richardsom, 1910 (Cymothoidae) from Marine fishes of Karachi coast. Proc. Parasitol. 1998, 26, 55-62.

82. Martin, M.B.; Bruce, N.L.; Nowak, B.F. Smenispa irregularis (Bleeker, 1857) (Crustacea: Isopoda: Cymothoidae), a buccal attaching fish parasite from Australia. Rec. Aust. Mus. 2014, 66, 233-240. [CrossRef]

83. Schioedte, J.C.; Meinert, F.W. Symbolae ad Monographiam Cymothoarum Isopodum Familiae 4. Cymothoidae. Trib. II. Cymothoinae. Trib. III. Livonecinae. Nat. Tidsskr. 1884, 3, 221-454.

84. Richardson, H. Description of a new species of Livoneca from the Atlantic coast of Panama. Proc. U.S. Natl. Mus. 1905, 29, 445-446. [CrossRef] 
85. Smit, N.J.; Bruce, N.L.; Hadfield, K.A. Global diversity of fish parasitic isopod crustaceans of the family Cymothoidae. Int. J. Parasitol. Parasites Wildl. 2014, 3, 188-197. [CrossRef]

86. Leonardos, I.; Trilles, J.P. Host-parasite relationships: Occurrence and effect of the parasitic isopod Mothocya epimerica on sand smelt Atherina boyeri in the Mesolongi and Etolikon Lagoons (Greece, W.). Dis. Aquat. Org. 2003, 54, 243-251. [CrossRef]

87. Trilles, J.P.; Ravichandran, S.; Rameshkumar, G. Catoessa boscii (Crustacea, Isopoda, Cymothoidae) parasitic on Carangoides malabaricus (Pisces, Carangidae) from India. Taxonomy and host-parasite relationships. Acta Parasitol. 2012, 57, 179-189. [CrossRef]

88. Sasal, P.; Thomas, F. Behavioural aspects of parasitism. In Marine Parasitology; Rohde, K., Ed.; CABI Publishing: Wallingford, UK, 2005; pp. 259-264.

89. Ravi, V.; Rajkumar, M. Effect of isopod parasite, Cymothoa indica on gobiid fish, Oxyurichthys microlepis from Parangipettai coastal waters (South-east coast of India). J. Environ. Biol. 2007, 28, 251-256.

90. Brusca, R.C.; Gilligan, M.R. Tongue Replacement in a Marine Fish (Lutjanus guttatus) by a Parasitic Isopod (Crustacea: Isopoda). Copeia 1983, 3, 813-816. [CrossRef]

91. Spalding, M.D.; Fox, H.E.; Allen, G.R.; Davidson, N.; Ferdaña, Z.A.; Finlayson, M.; Halpern, B.S.; Jorge, M.A.; Lombana, A.; Lourie, S.A.; et al. Marine ecoregions of the world: A bioregionalization of coastal and shelf areas. BioScience 2007, 57, 573-583. [CrossRef]

Publisher's Note: MDPI stays neutral with regard to jurisdictional claims in published maps and institutional affiliations. 